\title{
Slit Homolog 3 Protein
}

National Cancer Institute

\section{Source}

National Cancer Institute. Slit Homolog 3 Protein. NCI Thesaurus. Code C126790.

Slit homolog 3 protein (1523 aa, 168 kDa) is encoded by the human SLIT3 gene. This protein plays a role in the modulation of cell migration. 